\title{
THE PROSPECTS FOR IMMIGRATION AMENDMENTS
}

\author{
HARRY N. RosenFIELD*
}

\section{THE Issues}

The perhaps overly ambitious task that this article undertakes is a definition and assessment of some of the more significant factors militating for or against revision of our immigration laws. For this purpose, it will be helpful initially to recognize that there are at least three kinds or levels of issues involved:

\section{General Policy Issues}

These are the broad questions of domestic and international policy, such as:

a. The general tone of the law. Should the "mood" of Congress" regard aliens as desirable additions to our body politic and social, as people who do not seek to subvert our institutions? Or should the tone be suspicious of aliens as "riff-raff," regarding immigration as perhaps a necessary but certainly a dangerous evil?

b. The number of aliens to be admitted annually. How should -we determine our national capacity to absorb immigrants? Should this number be fixed by statute, or should it be subject to periodic nonstatutory adjustment in the national interest?

c. The method of selection. Should immigrants be selected without regard to their individual merit, solely in terms of the accident of their birthplace or national origin? Or should they be chosen on the basis of their own potential contribution' to our national life?

\section{Specific Policy Issues}

These issues are of a somewhat more technical character, such as grounds for excluding or deporting aliens; bases for determining security considerations; and procedural rights of aliens.

\section{Technical Issues}

The McCarran-Walter Act ${ }^{2}$ is a long and complex law. Many questions relating to it are of a technical and administrative character, involving correction, clarification, simplification, and tightening or loosening up of unworkable provisions. Such amendments are especially important because of the law's defective draftsmanship. ${ }^{3}$

-A.B. I93I, College of the City of New York; LL.B. I934, Columbia University; J.S.D. I942, New York University. Member of the New York and District of Columbia bars; practicing attorney, Washington, D. C. Member, United States Displaced Persons Commission, r948-52; Executive Director, President's Commission on Immigration and Naturalization, 1952-53. Contributor to legal and other periodicals.

${ }^{1}$ Cf. Universal Camera Corp. v. NLRB, 340 U. S. 474, 487 (I95I).

2 The Immigration and Nationality Act of I952, 66 STAT. $x 63,8$ U.S.C. $\$ \$ x$ rox-503 (I952).

3 "The Attorney General pointed out that, from the standpoint of effective administration, the Immigration and Nationality Act of 1952 requires amendment and clarification, and further that a number 
In the light of these issues, this article will address itself to the following questions:

I. Whether: will there be any amendments to the 1952 Immigration Act?

2. How: in what form will they come about-through a frontal attack on the present law or through piecemeal amendments?

3. What: what will such amendments, if any, provide?

4. When: what is the likely timetable for any possible amendments?

\section{The Partisan Political Front}

Immigration is a political issue, since it is decided within a political orbit, the Congress of the United States. This is as it should be, since all such basic national issues are political in this sense. But today, immigration seems no longer to be a partisan issue, because views on immigration cross political lines. There is major significance in this change from immigration as a partisan issue to immigration as a nonpartisan political issue.

In recent year, the strongest support for liberalizing amendments on the general policy issues seems to have come from Democratic former President Truman ${ }^{4}$ and from the northern wing of the Democratic Party-albeit some of the most vigorous restrictionists are from the Democratic Deep South. In the House, over 45 per cent of the Democrats, but only I2 per cent of the Republicans, voted to sustain President Truman's veto of the McCarran-Walter Bill; and similarly, in the Senate, $4 \mathrm{I}$ per cent of the Democrats but only 20 per cent of the Republicans, supported the president's action. 5 Thus, while both parties exhibited split personalities on this issue, the major congressional support for this legislation, percentage-wise, appears to have come from Republicans.

On the other hand, however, President Eisenhower has sent to Congress a special message on immigration, ${ }^{6}$ proposing substantial ameliorations of the nationalorigins system, although not its abandonment, as had been proposed by Senator Lehman and a group of senators. " But the Republican Party, as will be seen below, has boasted that the national-origins system was originated as a Republican policy, and the normally Republican Midwest has traditionally been as much opposed to substantial amendments of the present immigration policy as the Democratic South.

of the sections are ambiguous and otherwise defective." President's Comm'N on Immigration and Naturalization, WhoM We Shull Weicome i8 (1953).

'See his scathing veto of the McCarran-Walter Bill. H. R. Doc. No. 520, 82d Cong., $2 \mathrm{~d}$ Sess. (1952).

${ }^{5}$ In the House of Representatives, the veto was overridden by a vote of 278 to 113 . Among those voting to override, I7I were Republicans and I07 were Democrats; only 90 Democrats and 23 Republicans voted to sustain the veto. In the Senate, the vote was 57 to 26 , with 32 Republicans and 25 Democrats voting to override; only 18 Democrats and 8 Republicans voted to sustain the veto. 8 Cong. Q. Almansc 180, 184-85 (1952); see also Telford Taylor, Letter to the Editor, N. Y. Timcs, March 20, I956, p. 22, col. 7 .

${ }^{6}$ H. R. Doc. No. 329, 84th Cong., 2d Sess. (1956). See also ro2 Conc. Rec. 2061 (daily ed. Fcb. 8, r956).

"S. 1206, 84th Cong., rst Sess. (1955). For a résumé of this bill, sec ro1 Conc. Rec. 2094 et seq. (1955). 
There is much point, then, to the observation that congressional attitudes and voting records on immigration stem more from geographical than political affiliations. ${ }^{8}$ This would seem further to be borne out by the fact that immigration policy has long been recognized as a divisive issue within both the Democratic and Republican Parties. Thus, for example, fifty years ago, Speaker Cannon was opposed to any airing of the immigration question because it was likely to divide the Republican Party politically. ${ }^{9}$

\section{Party Platforms}

A review of political platforms during presidential elections of the last too years discloses a violent swing from an early liberal and favorable attitude, to a long period of restrictive desire to limit immigration, a period from which we have just begun to emerge.

The Democratic Party's platform of 1856 condemned "a political crusade . . . against . . . foreign born." 10 Then, silence prevailed in its platforms until 1876 , when there began a long period of planks calling for restriction on Oriental immigration or on immigration in general, except for the I 928 platform, which branded provisions separating families as "inhumane."11 A 1948 plank, however, condemned as discriminatory the Displaced Persons Act of $1948,{ }^{12}$ enacted by a Republican Congress; and in 1952 , for the first time since 1856 , the Democratic platform pledged the party to liberalized general immigration legislation, by urging "continuing revision of our immigration and naturalization laws to do away with any unjust and unfair practices against national groups."13

The Republicans had no platform statement on immigration until their third convention, in I864, when Abraham Lincoln helped to draft the plank which stated that "foreign immigration ... should be fostered and encouraged by a liberal and just policy." 14 This encouragement was restated in the 1868 and 1872 platforms, but from then until the present, there has been no similar Republican plank for a liberal immigration policy. Their pleas for restriction, instead, have roughly paralleled those of the Democrats. In the 1932 platform, the Republicans boasted that "the restriction of immigration is a Republican policy. Our party formulated and enacted into law the quota system. . . ."15 And although the $194^{8}$ platform

\footnotetext{
${ }^{8}$ Sce Schwartz, Immigration Policies: 1955, 29 CuRrent History 267, 268 (1955).

'See Hearings before the President's Commission on Immigration and Naturalization, 82d Cong., 2d Sess. I84I (r952).

${ }^{10}$ George D. Ellis, Platforms of the Two Great Political Parties, 1856 -x920, at 7 (1926).

${ }^{21}$ Leroy Brandon, Piatforms of the Two Great Political Parties, 1856-ig28, at 307 (1936).

1262 STAT. IO09, 50 App. U.S.C. $\$ \S$ I95I-63 (I952).

${ }^{13}$ Earl Rockwood, Platforms of the Two Great Political Parties, Supplement i952, at 9 (I952).

14 Ellis, op. cit. supra note I0, at 23.

16 William Graf, Platforms of the Two Great Political Parties, i932-i948, at 354 (1950). President Coolidge had, in fact, urged the enactment of restrictive legislation. See H. R. Doc. No. $I$, 68th Cong., rst Sess. (1923).
} 
took credit for the enactment of the Displaced Persons Act, ${ }^{16}$ nothing on the subject appeared in the $195^{2}$ platform.

\section{The Current Political Line-Up}

Historically, therefore, neither party has stood for a liberal immigration policy. Where do the parties stand today? President Truman's veto laid out the lines for the so-called liberal wing of the Democratic Party and for its national party position. He pointed to "the crying need for reform in the field of immigration." Of the quota system, he said that its "greatest vice ... is that it discriminates, deliberately and intentionally, against many of the peoples of the world." He bluntly charged that "the basis of this quota system was false and unworthy in 1924. It is even worse now." Truman urged Congress to take immediate remedial action on a wide front of policy issues as well as technical and administrative defects. ${ }^{17}$

The major legislative efforts to prevent enactment of the McCarran-Walter Bill and to crystallize opposition to it, moreover, were largely Democratic in origin and effort, led by Senator Herbert H. Lehman, of New York, with assistance, however, by both Democrats and Republicans. Furthermore, the senate Democratic majority leader, Lyndon Johnson, of Texas, has included the following pledge within his thirteen-point action program for congressional action in 1956: "Amendments to the immigration and naturalization laws to insure that they are fair and just"; ${ }^{18}$ and he has continued to urge action. ${ }^{19}$

Among the candidates for the 1956 Democratic presidential nomination, as well, Adlai Stevenson has described the racist assumption of the national-origins system as "preposterous," and has called attention to the recommendations of the President's Commission on Immigration and Naturalization of 1953, as well as to other specific proposals for amendment. ${ }^{20}$ "The worst thing about the law is the national origins quota system of selecting immigrants," he has said.21 Senator Estes Kefauver signed the minority report which opposed the McCarran-Walter Bill.92 And Governor Harriman, too, has openly and forcefully attacked the present law. ${ }^{23}$ Also of significant political import is the fact that the Democratic National Chairman, Paul M. Butler, has unequivocally repudiated the national-origins system. ${ }^{24}$

What of the Republicans? As a candidate in 1952, General Eisenhower directly attacked both the national-origins system and the McCarran-Walter Act. On October 2I, I952, he said: ${ }^{25}$

${ }^{10}$ See GraF, op. cit. supra note I5, at 440 .

${ }^{17}$ Op. cit. supra note 4 , at $\mathrm{I}, 3$, 4. President Truman had attacked the national-origins quota system earlier, in his message of March 24, 1952, proposing a special emergency program to follow after termination of the displaced persons program. See H. R. Doc. No. 400, $82 \mathrm{~d}$ Cong., $2 \mathrm{~d}$ Sess. (1952).

${ }^{18}{ }_{13}$ Cong. Q. 1260 (1955).

${ }^{19}$ See e. g., Chamber of Commerce of the U. S., Legislative Daily, April 13, 1956, p. 2.

${ }^{20}$ N. Y. Times, Feb. 26, 1956, p. 64 , cols. 3-8.

${ }^{21} 102$ Cong. Rec. 80-81 (daily ed. Jan. 5, 1956).

${ }^{22}$ S. REP. No. xi37, 82 d Cong., 2d Sess. pt. 2 (1952).

${ }^{23}$ See ror Cong. REC. A2469 (daily ed. April 14, 1955).

${ }^{24}$ Ibid.

${ }_{25}$ IOI Conc. REc. 10769 et. seq. (daily ed. July 30, 1955). 
No man's race or creed or color should count against him in his economic or civil or other rights. Only second-class Americanism tolerates second-class citizenship. Its time to get rid of what remains of both, and that includes rewriting the unfair provisions of the McCarran Immigration Act.

On October 29, I952, he said: "We need to rewrite the unfair provisions of the McCarran Immigration Act to get the bigotry out of it."26 On October 16, 1952, he said: ${ }^{27}$

... we must strike from our statute books any legislation concerning immigration that implies the blasphemy against democracy that only certain groups of Europeans are welcome on American shores.

And as President, his first State of the Union Message said: ${ }^{28}$

Existing legislation contains injustices. It does, in fact, discriminate. . . I am therefore requesting the Congress to review this legislation and to enact a statute which will at one and the same time guard our legitimate national interests and be faithful to our basic ideas of freedom and fairness to all.

In his special message to Congress, on February 8, 1956, the President, as has already been noted, did not recommend abandonment of the national-origins system. ${ }^{20}$ While that issue was being studied as he recommended, however, he urged Congress to set up a system of pooling unused quotas. ${ }^{30}$ Although it appears to compromise with the national-origins philosophy, this proposal, in fact, fundamentally discards its principles. In addition, the President has asked for an increase in the number of aliens to be admitted from 154,657 to approximately 220,000 annually, with a special quota of 5,000 to be admitted without regard to national origins. The President also has proposed technical amendments. ${ }^{31}$ This program has been introduced into both houses of Congress. ${ }^{32}$

Vice-President Nixon, too, who voted for the McCarran-Walter Bill, pledged himself, in the 1952 campaign, to the rewriting of that act without bigotry. ${ }^{33}$

A vital change, therefore, seems to have taken place in the last four years in the status of the immigration issue. From a somewhat partisan, relatively localized issue, it appears to have become a nonpartisan national issue. From the partisan jockeying of $195^{2}$ there seems to have developed substantial agreement by both major parties in 1956 that the basic features of the McCarran-Walter Act need thoroughgoing

${ }^{20}$ Ibid.

${ }^{27}$ See Corsi, Let's Talk About Immigration, The Reporter, June 2, I955, pp. 22, 26.

${ }^{28} \mathrm{H}$. R. Doc. No. 75, 83 d Cong., Ist. Sess. 13 (1953).

${ }^{20}$ See note 6 supra. See also N. Y. Times, May 25, 1956, p. I, col. I.

${ }^{30}$ For a Democratic bill on pooling quotas, see S. 1315, 84th Cong., Ist Sess. (1955).

31 The President's fourth proposal, on judicial review, is a limitation on a recent Supreme Court holding in Shaughnessy v. Pedreiro, 349 U. S. 48 (I955).

${ }^{32}$ See S. 3167-3170; H. R. 9180-9183, 84th Cong., 2d Sess. (1956). For a resumé, see ro2 Cong. REc. 2142 et seq. (daily ed. Feb. 9, 1956).

${ }^{33}$ See Wasserman, The Immigration and Nationality Act of 1952-Our New Alien and Sedition Law, 27 TEMP. L. Q. 62 n. 5 (1953). 
changes. Revision of the immigration law has finally achieved political maturity as a national issue.

If further proof is necessary of the nonpartisan character of the issue, it can be seen in connection with the inaugural dinner, of April 9, x956, of the National Committee on Immigration and Citizenship, an educational organization whose purpose is "to carry on a program of education aimed at bringing the widest possible study and evaluation of our immigration and citizenship policies." ${ }^{34}$ The Committee's first principle is that "the allocation of immigration visas should be free from any implication of superiority between peoples because of race, nationality, or religion."35 The meeting was addressed by Republican Governor Knight, of California, and Democratic Governor Muskie, of Maine, and received greetings from some twenty other governors in support of its aims. Although one of its principal founders is Democratic Senator Lehman, the Committee received the following message from President Eisenhower: ${ }^{36}$

Please extend my greetings to all attending the April ninth inaugural dinner of the National Committee on Immigration and Citizenship. It is gratifying to learn of the Committee's program to inform the American people about our nation's immigration and citizenship policies. All of you have my best wishes for success in this undertaking.

The present political balance, thus, seems to have assumed this posture:

I. The very top leaders of both political parties have put themselves squarely on record in favor of substantial and basic amendments to the McCarran-Walter Act.

2. The Democratic Party's leaders have taken a more liberal and positive position on the general policy issues by urging outright repeal of the national-origins system. As a political party, the Democrats have also taken an early lead by adopting a liberalization platform plank.

3. The Republican Party has been more cautious and has not had a platform plank in recent years, although in view of President Eisenhower's special message, it is reasonable to assume that its 1956 platform will contain a plank urging liberalization of our immigration laws. As a party, the Republicans now have captured the initiative from the Democrats.

4. The issue is more largely geographic than partisan political, and both parties have splits within their own ranks on the basic policy.

5. For the first time in Ioo years, both political parties will, in all likelihood, have party platforms urging substantial liberalization of our immigration laws.

6. Immigration has emerged from its role as a partisan question and has become

st National Committee on Immigration and Citizenship, Program Announcement, Inaugural Dinncr, New York City, April 9, 1956.

${ }^{35}$ Provisional National Commite on Immigration and Citizenship, a Statement of Principles and an Outuine of Structure and Program i (1955).

${ }^{36}$ See Press Release, April 9, 1956. 
a nonpartisan political issue, ${ }^{37}$ with differences being more in the nature of "how much" rather than "whether." This is not to say that there have not been differences between the two major parties on the subject; $;^{38}$ the important development is, however, that both political parties now seem to be committed to substantial liberalization of the immigration law.

\section{The Role of President}

The President is one of the only two public officials (the other being the VicePresident) who are elected by all the people of the United States. He represents all of the people, not those of any particular geographic, economic, cultural, ethnic, or other constituency. Historically, he has been the only vehicle for expressing the national, rather than regional or local, aspirations and policies of the American people.

In American immigration history, the President has represented traditional American liberal policy, defending American ideals and humanitarianism against periodic congressional onslaughts. For example, bills for a literacy test, designed to restrict immigration, ${ }^{39}$ were vetoed by three Presidents: Cleveland in I897, Taft in I9I3, and Wilson in I9I5, all of whom objected that literacy was not a fit test of the character of a prospective immigrant. ${ }^{40}$ Wilson also observed that it was a violation of basic American traditions of welcome; ${ }^{41}$ his veto, however, was overridden by Congress. ${ }^{42}$ Truman's veto was in this same presidential tradition. Later, in the 1952 campaign, he charged that "the whole statute breathes prejudice against the foreign born alien and naturalized citizens alike," and that the law was "unfair and un-American." 43

Prior to President Eisenhower's special message to Congress, The Christian Century editorialized that any successful effort to amend the present law will require "President Eisenhower to throw himself actively and decisively behind the effort to amend."44 To this end, sending up his special message was a necessary first step, but it is not, in itself, sufficient. President Eisenhower has enormous prestige and influence with the people and the Congress, and, as president, he cannot sidestep his role as a "Leader of Legislation." T5 The effective use of all his prestige and power in

${ }^{37}$ See testimony of Senator Lehman, Hearings before Subcommittee on Immigration and Naturalization of the Senate Committee on the Judiciary, 84th Cong., $2 \mathrm{~d}$ Sess. 2 Transcript Ix 5 (unpublished 1955).

${ }^{38}$ Sec Lefever, The Protestant Nonpolitical Approach to Politics, 38 Christian Scholar 90, 97 (x955).

${ }^{30}$ See S. Rep. No. 290, 54th Cong., Ist Sess. 22-23 (1895); S. Rep. No. 355, 63d Cong., 2d Sess. 2 (I913); Comm'r of Immigration, Report 23 (i923).

${ }^{\circ} \mathrm{Sce}$ W. S. Bernard and Others, American Immigration Policy-A Reappraisal i4 (1950).

${ }^{42}$ See H. R. Doc. No. 1527, 63d Cong., 3d Sess. (1914); H. R. Doc. No. 2003, 64th Cong., Ist Sess. (I9I5).

'2 Such vetoes were in an earlier tradition tracing back to Madison's denunciation of the Alien and Sedition Acts. See Madison's Report on the Virginia Resolutions, 4 Jonstrin Ellor, ConstiturtonsI Debates 554 (1937).

3 Wasserman, stipra note 33 , at 62 .

472 Christian Century 1419 (1955).

45 Cf. Rossiter, The Presidents and the Presidency, 7 American Heritage 28 (1956). 
dealing with Congress will be necessary if present efforts to modify the immigration law are to succeed; ${ }^{46}$ half-hearted, inactive, or disinterested support by the President may well doom even the most vigorously-pressed efforts of others.

\section{The Congressional Picture}

Congressional machinery dealing with immigration matters (control over the Judiciary Committees) is in the hands of powerful and determined supporters of the present law, who often make personal attacks upon the law's opponents and impugn their patriotism and loyalty. ${ }^{47}$ The prospects for amendment were brighter until recently. ${ }^{48}$ Senator Harley M. Kilgore, of West Virginia, who had succeeded Senator Pat McCarran to the chairmanship of the Senate Judiciary Committee, had been one of the leaders in the successful bipartisan fight to amend the Displaced Persons Act of $19488^{40}$ He later signed the minority report to the McCarran-Walter Bill, and co-sponsored a substitute for it. ${ }^{50}$ On assuming the committee chairmanship, he started hearing on basic immigration policy, but he died before they were concluded.

The Senate Judiciary Committee chairmanship has now passed, by seniority, to Senator James O. Eastland, of Mississippi. Here is an example of what the philosopher Morris R. Cohen called the role of accident in history ${ }^{51}$ and of individuals in the course of history. ${ }^{52}$ With Senator Eastland's chairmanship and the resulting staff changes, the pendulum has swung back; vigorous and resourceful defenders of the McCarran-Walter Act are again in the driver's seat in the Senate.

The Senate Judiciary Committee is composed of fifteen members, of whom eight are Democratic. Not a single Democrat on this vitally important committee comes from a state north of the Mason and Dixon line, except for Senator O'Mahoney, of Wyoming; not one of its Democratic members comes from the northern states deeply interested and concerned with liberal immigration laws. By and large, restrictionist sentiment is found largely in the areas of greatest ethnic homogeneity, ${ }^{\text {53 }}$ - principally in the states dominated by the rural point of view. ${ }^{54}$ Therefore, this pre-

\section{(1952).}

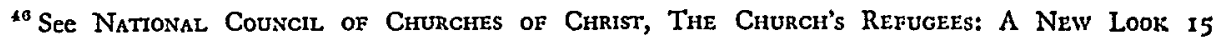

${ }^{47}$ Exception to this issue-begging proclivity is taken by a Jesuit magazine: "This Review has fought the McCarran-Walter bill, and has reported various expressions of Catholic opposition. . . " 88 AMERICA 390 (1953).

${ }^{48}$ See American Federation of International Institutes, National Newsletter, April 17, 1956, p. 11.

${ }^{40}$ Some of the story of how Senator Kilgore accomplished this task is told in S. K. BAILEY \& H, D. Samuer, Congress at Work 236-67 (I953).

${ }^{50}$ S. 2343, 82d Cong., Ist Scss. (1951).

"see Morris R. Cohen, The Menning of Human History 90 (1947); see also L. C. Rosenfield, Morris R. Cohen's "Philosophy of History," in Proceedings of the Tenth International Congress or Philosophy 995, 997 (I949).

${ }^{52}$ See CoHEN, op. cit. supra note 5I, c. 7 .

${ }^{63}$ See American Jewish Committee, Americanizing Our Immigration Law 8o et seq. (Felix S. Cohen ed. 1949).

Ef To some extent, a dent in this historic pattern has been caused by the systematic resettlement distribution of displaced persons, under the Displaced Persons Act, throughout all parts of the United States. See Displaced Persons Comm'n, The DP Story 248 et seq. (1952). Even Senator Eastland, 
dominance of Southerners on the Democratic side of the Judiciary Committee would seem to have a deterrent effect on the likelihood of liberalizing amendments.

On the Republican side, the chairman of the Judiciary Committee during the last Republican-controlled Senate was Senator William Langer, of North Dakota, who also signed the minority report against the McCarran-Walter Bill, and is a co-sponsor of the Lehman Bill to abolish the national-origins system. However, Senator Arthur V. Watkins, of Utah, is the ranking Republican member of the immigration subcommittee. His views on national origins were expressed during the senate subcommittee hearings in late 1955: "I still think there must be some merit to at least basically those principles upon which the law has been passed." 55

In the House, Emanuel Celler, of New York, Chairman of the Judiciary Committee, is a strong opponent of the McCarran-Walter Act and the sponsor of legislation identical with the Lehman Bill. ${ }^{56}$ However, the Judiciary Committee, as a whole, has a history of being more sympathetic, on immigration matters, to the lead of Francis E. Walter, of Easton, Pennsylvania, chairman of the immigration subcommittee and a co-sponsor of the present law. The ranking Republican on the House Judiciary Committee is Kenneth B. Keating, of Rochester, New York, who voted to sustain President Truman's veto and has introduced President Eisenhower's immigration program. ${ }^{5 \pi}$

\section{The Attitude of the American People}

Congress passed the McCarran-Walter Bill and then overrode the President's veto by a two-thirds vote of each house of the Congress. Does that represent the attitude of the American people?

There is substantial reason, based on reliable evidence, to believe that the McCarran-Walter Act does not represent the views of the informed people in the United States. A switch of only two votes in the Senate or eighteen votes in the House would have defeated the bill in the vote on the President's veto. And even this narrow margin was not really representative of the full Congress. Senator Lehman has said that there were "sufficient votes to sustain the President's veto if we could have gotten our people there. We were forced to bring this thing to a vote." ${ }^{n 8}$ The veto was overridden through clever parliamentary maneuvering that took advantage of absences of senators from the floor. ${ }^{59}$

There is positive and persuasive proof that informed public opinion is opposed to the McCarran-Walter Act. In the fall of 1952, President Truman appointed a

an arch opponent of liberalizing immigration amendments, has personally sponsored refugees for his own plantation, under the Refugee Relief Act of 1953, 67 STAT. 400, 50 App. U.S.C. \$ 1971 (Supp. 1955). See American Federation of International Institutes, stipra note 48, at 12.

EE Hearings, supra note 37 , at I Transcript 39 .

${ }^{60}$ H. R. $4430,84^{\text {th }}$ Cong., Ist Sess. (1955).

${ }^{57}$ H. R. 9180-9183, 84th Cong., 2d Sess. (1956). Senator Watkins introduced the same program, S. 3167-3170, 84th Cong., 2d Sess. (1956).

${ }_{68}$ Hearings, supra note 37 , at 2 Transcript 146 .

${ }^{20}$ Sce Wasserman, stipra note 33 , at 62 n. 2. 
nonpartisan ${ }^{60}$ Commission on Immigration and Naturalization to study and report on the subject. ${ }^{12}$ This Commission did what the Judiciary Committees did not do -it sought the grass-roots views of the American people at the local level. The Commission held thirty sessions of public hearings in eleven major cities spread across the nation from the Atlantic to the Pacific oceans. Defenders of the McCarran-Walter Act are fond of pointing to their product's long period of gestation. Their public hearings were held in Washington, and only ninety-four statements and witnesses were heard. In the President's Commission's hearings, on the other hand, every shade of opinion, pro and con, from every walk of life, and from every kind of representative organization was solicited and heard; the Commission heard 634 witnesses or statements, representing 1,000 or so persons and organizations. These were the most extensive public hearings on immigration in some forty years; the record of the Commission's hearings took 2,089 pages of small type to print. ${ }^{22}$

Out of this extraordinary public outpouring of representative public opinion, the real attitude of the American people can be discerned. What did the President's Commission find? Its report, Whom We Shall Welcome, says: ${ }^{63}$

The Commission was surprised to learn of the widespread and rather determined opposition to the act of 1952 . This is all the more amazing in light of its recent passage over the President's veto. ... The dominant theme of those who appeared to testify or file statements was criticism of the act of 1952. Some objected to specific aspects, but most witnesses opposed the basic theories of the new law.

The Commission found that one of the major recurrent suggestions was that the national-origins system should be abolished. ${ }^{64}$

It is not difficult to interpret this seeming incongruity between Congress' overriding the President's veto in June 1952 and the representative expression of the views of the American people themselves in September and October 1952, when the Commission's hearings were held. The American people did not know what was in their immigration law. In particular, the national-origins system was originally enacted through what amounted to a sneak play on the Congress itself as well as on the American people, and there is very considerable mystery as to the system's development. ${ }^{65}$ In the early twenties, the major effort to enact restrictive immigration legislation was through the literacy test, not national origins. The nationalorigins proposal "seemed to come in as an afterthought without any major public discussion." Congress had no major discussion of the national-origins system;

\footnotetext{
${ }^{\circ 0}$ See Editorial, Washington Post and Times Herald, July 12, 1955, p. 22, col. 1.

01 The Commission was established by Executive Order No. 10392, Sept. 4, 1952, 17 Fed. REo. $806 x$ (1952).

'Hearings, supra note 9 .

as President's Comm' $N$ on Immigration and Naturalization, op. cit. supra note 3, at 7. President Truman formally submitted this report to Congress, Jan. 13, 1953, and urged "earnest and prompt consideration" of its conclusions. 99 CoNG. REc. 376 (1953).

${ }^{64}$ See President's Comm'n on Imaigration and Naturalization, op. cit. supra note 3, at 7.

${ }^{\circ}$ See id. at $87-88$.

${ }^{60}$ Id. at 87 .
} 
although the debate on the I924 Immigration Act took some 500 pages of the Congressional Record, only $\mathrm{I}_{4}$ were devoted to a consideration of the national-origins system, and only a small minority of Congress even participated in that sparse discussion. It was passed without a roll-call in the Senate, after having been voted down several times in the House; ${ }^{\mathbf{6 7}}$ it was enacted on the basis of a conference report which did not discuss the matter and after debate, almost none of which was devoted to the national-origins system. ${ }^{68}$

\section{Gallup Poll}

In June I955, three years after the enactment of the present law, a Gallup Poll ${ }^{69}$ found that "a majority of Americans are not familiar with the controversial McCarran-Walter Act." The Poll asked those persons who were familiar with the law: "From what you know, do you think there should or should not be changes made in the McCarran-Walter Act?" The replies were as follows:

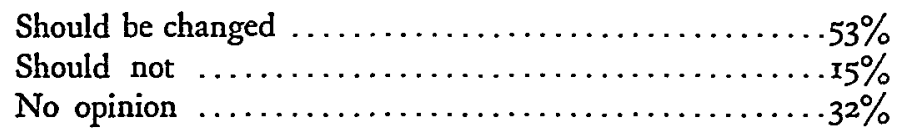

Thus, without overestimating the accuracy of any poll in the representation of popular opinion, it would seem that a substantial majority of the informed American people not only do not approve of the Immigration and Nationality Act, but actually want Congress to change it. What kind of change do they want? The pollsters asked the following question of the fifty-three per cent who wanted change: "Do you think this act should be made more strict or more liberal?" The answers were:

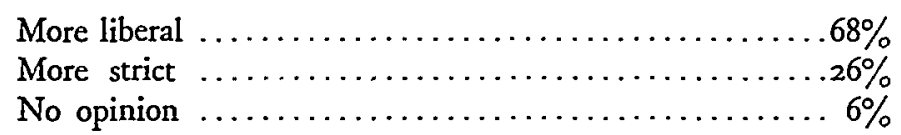

This evidence seems to show that neither the McCarran-Walter Act nor the national-origins system in any sense reflect the wishes or attitudes of the American people. On the contrary, a substantial preponderance of informed American public opinion seems to be opposed to the McCarran-Walter Act and wants it liberalized.

\section{Organized Public Opinion}

Are laws passed by Congress the expression of a knowable public interest, based upon felicitous compromise and ethical awareness? Or are they the morbid distilation left by armies of pressure groups who clash blindly in the night? . . . These questions . . . will not be settled in our time, if ever, but no one indiivdual can afford to leave them hanging. ${ }^{70}$

${ }^{a 7}$ Sec H. R. R'ep. No. 1365, 82d Cong., 2d Sess. 22 (1952).

${ }^{88}$ See Hearings, stupra note 9, at 309-ro.

${ }^{\circ 0}$ Hearings before the Subcommittee of the Senate Committee on the Judiciary on S. 1794, S. 2113, and S. 2419, 84th Cong., Ist Sess. 245 (1955). See also ror Cosc. Rec. 10789 et. seq. (daily ed. July 30, 1955).

${ }^{70}$ BaILey \& SaMuel, op. cit. stpra note 49, at 2. 
Group pressures have exercised enormous influence upon our immigration laws. At the time of the enactment of the $195^{2}$ Act, these pressures came almost wholly from its supporters. Other articles in this symposium will discuss and evaluate some of the motivations for such advocacy, such as xenophobia, fear of subversion, economic uncertainty, and satisfaction with our existent ethnic composition. One thing is clear, however; that the groups who opposed the McCarran-Walter Bill did not awaken, until too late, to what was taking place. The opponents of the 1952 Bill were either asleep at the switch, too poorly organized, or completely preoccupied with administrative and other responsibilities, especially in connection with the then-being-completed displaced persons program.

Among the major pressure groups which have vigorously supported the present restrictive immigration law are the American Legion, ${ }^{71}$ the DAR, ${ }^{72}$ the Junior Order of United American Mechanics, ${ }^{73}$ and specially organized pressure ${ }^{74}$ or fringe ${ }^{75}$ groups of one kind or another. A constant theme of the proponents of the law is an attack on the patriotism of the law's opponents. ${ }^{76}$

"The widespread and rather determined opposition to the act of 1952" which was found by the President's Commission on Immigration and Naturalization ${ }^{77}$ had been largely dormant during congressional consideration of the McCarranWalter Bill. It was partly awakened by the determined stand taken by a small group of senators who sought to argue the issues of basic policy, only to be rebuffed by Senator McCarran and the proponents of the bill, who refused to discuss the merits or policy involved. ${ }^{78}$ President Truman's veto message brought the issue out in the open.

The General Board of the National Council of Churches of Christ in the United States of America asked President Truman to appoint a Commission to study the matter. In August 1952, within two months of the enactment of the I952 law, a proposal to this same effect, the creation of a Commission to study the basic assumptions of our immigration law, was jointly signed by representatives of the Church World Service (of the National Council of Churches of Christ), the War Relief Services (of the National Catholic Welfare Conference), the United Service for New Americans (a Jewish migration agency), and the National Lutheran Council. And in September 1952 , before the McCarran-Walter Act went into effect,

${ }^{71}$ See Hearings, supra note 9, at $\mathrm{x628}$; Hearings, stlpra note 37 , at 2 Transeript 339; 14 Cono. Q. $50(1956)$.

72 Hearings, supra note 9, at $190,5 \mathrm{I} 3$; roI Cong. REc. A5I33 (daily ed. July 13, 1955).

${ }^{73}$ See Hearings, stupra note 9, at 1635; 101 Cong. Rec. A3775 (daily ed. May 31, 1955).

${ }^{*}$ E.g., The Alliance, see Coneuest va Immigration (1956); For America, see 13 Cong. Q. 1249 (1955); and American Coalition. See Call to Action, Nov. 25, 1955.

${ }^{7} \mathrm{See}$, e.g., Cimzens Congressional Committee to Abolish the United Nations, Auxiliary to the Christian Nationalist Crusade, Abolish the United Nations: A Handbook for Patriots 29 (n.d.); National Economic Council Letter No. 304, Feb. I, 1953; No. 313, June 15, 1953; The Cross and the Flag, Feb. 1953, p. 7 (founded by Gerald L. K. Smith).

${ }^{76}$ See, e.g., Matthews, Immigration-1956 Isste, The American Mercury, Oct. 1955, p. 51.

${ }^{77}$ President's-Comin's on Immigration and Naturalization, op. cit. stipra note 3 , at 7 .

${ }^{78}$ See the testimony of Senator Lehman, Hearings, supra note 37 , at 2 Transcript i15 et seg. 
the General Convention of the Protestant Episcopal Church urged the appointment of a Commission "to review [among other things] our permanent immigration policy and its basic assumptions."79 This was, of course, locking the barn door after the horse had been stolen. But these were the groups whose joint efforts had been responsible for the enactment of the Displaced Persons Act of 1948 and for its amendment in $1950^{80}$ Consequently, when President Truman acceded to these requests and appointed the President's Commission on Immigration and Naturalization in September I952, these major religious-and other-groups were ready to testify.

The desire of the President's Commission to hear testimony on general policy, unencumbered by specific technical or legalistic provisions of proposed bills, afforded the American people and their representative organizations their first real opportunity to talk to the basic assumptions of policy underlying the immigration and nationality law. These representative hearings disclosed fundamental and overwhelming opposition to the national-origins system and to the restricted number authorized to be admitted.1

A wide variety of important, representative, and powerful groups opposed the McCarran-Walter Act. First, there were veterans' groups. The American Veterans' Committee forthrightly opposed the national-origins quota system, among other features of the law. ${ }^{82}$ Vigorous and generalized opposition was also expressed by the Catholic War Veterans ${ }^{83}$ and the Jewish War Veterans. ${ }^{84}$

\section{Religious Groups}

All of the major religious faiths, through their representative organizations, have expressed their opposition to the McCarran-Walter Act. In the 1955 senate hearings, for example, Dr. Eugene C. Blake, President of the National Council of Churches of Christ, representing some 35,000,000 Protestants in America, testified: ${ }^{\mathbf{3}}$

The National Council of Churches believes the quota system, as embodied in existing legislation, should be made more flexible. . . . We believe, however, that restriction as to numbers should not involve discriminations, predicated upon national origins or racial heritage. ...

Rev. Walter W. Van Kirk, Executive Director of the Department of International Good Will of the National Council of Churches, had testified before the President's Commission: ${ }^{86}$

\footnotetext{
To President's Comm'n on Imsigration and Naturalization, op. cit. stpra note 3, at xi; National Council of Churches of Christ, Information Service, April 4, 1953, p. 3

${ }^{80}$ See Displaced Persons Comin's, op. cit. supra note 54, at 293.

${ }^{81}$ See President's Comm'n on Immigration and Naturalization, op. cit. supra note 3 , at 13.

${ }^{82}$ See Hearings, supra note 9, at 1655 ; Hearings, supra note 37 , at 3 Transcript 348.

${ }^{83}$ Sec Hearings, stura note 9 , at 1633 .

${ }^{\text {Bt }}$ See id. at 1649 .

ss Hearings, supra note 37 , at I Transcript $9 \mathrm{I}$.

${ }^{80}$ Hearings, supra note 9, at $\mathbf{x}_{508}$. The "we" was a delegation of ten top-level officials, including representatives of the Baptist World Alliance and the Presbyterian and Episcopal Churches.

${ }^{87}$ N. Y. Times, Nov. II, I955, p. 22, col. 2.
} 
We do feel very strongly that the law placed upon the statute books in the last session of the Congress [McCarran-Walter Immigration Act] is an affront to the conscience of the American people. We are going to work for the amendment of that legislation, and if we can't get it in the next Congress we will work for it until we get it. And it is for the purpose of conveying to you this aroused conscience on the part of the Protestant and Orthodox churches of the country, primarily for that reason, that we are in your presence this morning.

And at its Triennial Assembly, in November 1955, the United Church Women, a General Department of the National Council of Churches of Christ, adopted the following resolution: ${ }^{87}$

We urge a thorough revision of the McCarran-Walter Immigration Act of 1952 to eliminate such undemocratic practices as ( 1 ) inequalities in the quota system; (2) discrimination based on race. ...

The Department of Christian Social Relations and Local Church Activities of the Methodist Church adopted the following resolution on April 14, 1953:

That we work with all urgency for the revision of the McCarran Act ... as speedily as possible. Such revisions should provide for the admission of from 250,000 to 300,000 immigrants a year, without any discrimination based on race, national origin, or sex....

And Methodist Bishop G. Bromley Oxnam charged that the good in the McCarranWalter Act was "submerged in bad philosophy, archaic provisions and un-American procedures." 88 The American Baptist Convention also asked for a revision so that the law would be "more in keeping with our democratic tradition." 80

In January 1956, a group of Protestant and other organizations sponsored the publication of a pamphlet entitled The Fence, which calls the national-origins system "un-American" and urged revision of the law. Among the sponsors of this publication were the Board of Christian Education of the Presbyterian Church; the Church Peace Union; the Council for Social Action, Congregational Christian Churches; the Council on Christian Social Progress, American Baptist Convention; the General Department of United Church Women, National Council of Churches of Christ; and the Women's Division of Christian Service of Board of Missions of the Methodist Church.

The National Lutheran Council has "the firm conviction that the existing legislation has serious shortcomings." Its resolution of February 10, 1956, calls for "equality of opportunity for all races." An earlier annual resolution asked for a "just and workable" nondiscriminatory substitute for the 1952 Act."1 A representative of the Missouri Synod-Lutheran Church told the President's Commission that: ${ }^{\text {22 }}$

${ }^{87}$ N. Y. Times, Nov. 11, 1955, p. 22, col. 2.

${ }^{88} 9$ Cong. Q. Alasanac 242 (I953).

${ }^{80} \mathrm{Ibid}$.

${ }^{\circ 0}$ Resolution on Immigration Legislation, adopted by National Lutheran Council at its Annual Meeting, Feb. Io, 1956.

${ }^{92}$ N. Y. Times, Feb. 6, 1953, p. 7, col. т.

02 President's Comm'n on ImMigration and Naturalization, op. cit. supra note 3, at 49; Hearings, supra note 9 , at 565 . 
Some of the things which I read in Public Law 4I4 [McCarran-Walter Act] seem more akin to the superiority complex that was spawned out of the foulness of Nazism than to the humanitarian attitude which our fathers taught us.

The American Friends Service Committee has also publicly disapproved the McCarran-Walter Act. ${ }^{93}$ The Church Peace Union recently stated: "The McCarranWalter Act is a complete denial of our philosophical, political, economic and religious heritage," and is a betrayal of the principle that "all men are created equal."94

Other powerful forces in the Protestant church have said that "McCarran Act Revision [is] a Church Priority." Under that title, the undenominational The Christian Century editorialized that "a widespread church effort to revise the law should be undertaken. . . ."95 This editorial was of such importance that it prompted an attempted rebuttal by Senator McCarran himself. ${ }^{90}$ A more recent editorial in the same journal states: "Its basing of the selection of prospective immigration on national origins rather than on physical, mental and moral fitness, should be changed."

The Catholic Church has also vigorously, and over a long period, attacked the national-origins quota system. Archbishop Cushing, of Boston, stated to the President's Commission that: ${ }^{98}$

The theory of national origins cannot be defended without recourse to the discredited and un-Christian tenets of racism. ... It is my considered opinion that the act should be amended to purge it of several un-Christian and un-American provisions.

And after the report of the President's Commission appeared, the Archbishop urged adherence to its recommendations as a basis of an educational campaign. ${ }^{99}$ More recently again, he urged re-evaluation of our basic national-origins quota philosophy. ${ }^{100}$ Recently, Archbishop O'Boyle, of Washington, D. C., too, called for a liberalized immigration policy to admit 250,000 immigrants each year and opposed the continuance of the national-origins system. ${ }^{101}$

Before the President's Commission, the Director of the Bureau of Immigration of the National Catholic Welfare Conference testified that with reference to the assignment of quotas, the NCWC "has always regarded the policy adopted in the I920's as unfair, unscientific and highly discriminatory." He cited a long list of

${ }^{03}$ See Hearings, supra note 9, at 1522. See also statement, Immigration and Citizenship, adopted by the General Committee of the Friends Committee on National Legislation, Annual Meeting, Dec. 3-4, 1955.

${ }^{0}$ Rev. Ralph W. Sockman, President, The Church Peace Union, Letter to the Editor, N. Y. Times, Feb. 17, 1956, p. 22, col. 6.

95 70 The Christian Century 275 (1953).

Do Id. at 419 .

${ }^{07} 73$ id. at 227 (1956).

${ }^{o \theta}$ Hearings, supra note 9, at 313, 3I4; President's Comm'n on Ixmmgration and Naturalization, op. cit. supra note 3 , at 117 .

${ }^{00}$ See Cushing, U. S. Immigration Policy, 51 The Catholic Mrnd 364, 367 (I953).

${ }^{100}$ See ror Cong. Rec. A5531 (daily ed. July 27, 1955).

${ }^{101}$ See N. Y. Times, Dec. 6, 1955, p. 21, col. 3. See also I02 Cong. Rec. Ar442 (daily ed. Feb. I6, 1956). 
official statements, starting in 1924, from representatives of this major Catholic body, opposing the national-origins quota system. ${ }^{102}$ Further, leading Catholic journals have openly and aggressively attacked the McCarran-Walter Act and have asked for its basic amendment. Thus, The Commonweal said of the national-origins system: "Such racist notions were completely without scientific basis, of course, and the decades since then have given them the lie."103 And again: "America's immigration laws are now, and have long been, unfair. They discriminate grossly."104 The Jesuit magazine, America, also editorialized as follows: "Purely arbitrary barriers to immigration are an offense against the moral law. ..."105

The Synagogue Council ${ }^{106}$ and various other representative Jewish groups ${ }^{107}$ have also urged that the McCarran-Walter Act be amended in a wide variety of ways, including elimination of the discriminatory national-origins system.

\section{Voluntary Agencies}

A relatively new force of great strength is the operating immigration agency. Among the major such agencies, which largely matured under the displaced persons program, are the Church World Service, War Relief Services, the Lutheran Resettlement Service, and the United HIAS Service. The Displaced Persons Commission said that the voluntary agencies "had a leading role ... in general relations with the public" and that they "served as focal points of public expression" in the legislative struggles of the displaced persons program. "Without the voluntary agencies, there never would have been a displaced persons program to begin with."108

These voluntary agencies have given a "new look" to immigration. They not only have the humanitarian motivations of their religious orientation, but as operating agencies, they are immigration experts with vast know-how, close contacts with representative local affiliates throughout the nation, and a vested interest in liberal immigration legislation. Both as adjuncts to their parent organizations and in their own right, the voluntary agencies are playing an exceedingly important role in the development of a new and liberalized public policy on immigration.

Influential nationality groups are also a reservoir of opposition to the McCarranWalter Act, ${ }^{109}$ although not all nationality groups are committed to liberalizing amendments. ${ }^{110}$

${ }^{102}$ Hearings, supra note 9, at $1737-38$.

${ }^{103} 63$ The Commonweal 295 (1955). (x953).

${ }_{105} 93$ AMerica 255 (I955). See also O'Grady, Number I Problem: Immigration, 88 America 392

${ }_{100}$ See Hearings, supra note 9, at 117; Hearings, stupra note 37 , at 2 Transcript 176.

${ }^{107}$ See ror Cong. Rec. A4033 (daily ed. June 7, 1955); $i d$. at Ar 472 (daily ed. March 7, 1955).

${ }^{108}$ Displaced Persons Comm's, op. cit. silpra note 54, at 267, 293, 294.

${ }^{100}$ See, e.g., ror CoNG. REC. A36II (daily ed. May 24, 1955) (Italian); id. at A5316 (daily cd. July 20, 1955) (Greek); 88 AMrerica 390 (1953), and Hearings, stupra note 9, at 824 (Polish); id. at 812 (Slovak); id. at 84I (Czech). On May 20-21, 1956, a National Convocation on Immigration and Naturalization was held in Washington, D. C., co-sponsored by many nationality groups, among others. See Washington Post \& Times Herald, May 21, 1956, p. 22, col. 1-2.

${ }^{110}$ See, e.g., Hearings, stpra note 9, at 1729 (German); id. at I729 (Japanese). But sec Tanaka, Postscript, The Colorado Times, May 5, 1952. 


\section{Organized Labor}

For many years, labor was a strong advocate of restrictive immigration legislation. This situation has changed, ${ }^{111}$ and the significance of labor's new attitude cannot be overestimated. Now, major labor leaders and powerful labor unions support and vigorously espouse fundamental liberalization of the immigration law. At the President's Commission's hearings, Walter Reuther, then president of the CIO, strongly attacked the national-origins system. ${ }^{112}$ The American Federation of Labor also testified that the McCarran-Walter Act "falls shamefully short of the essential requirements of sound public policy," and stated that an authorized entry of somewhere between 200,000 to 250,000 aliens annually would be in the national interest. ${ }^{113}$ And in December 1955, at the first AFL-CIO Annual Convention after the two labor organizations merged, a resolution was adopted concerning the McCarranWalter Act: ${ }^{114}$

Nearly three years of operation of this law have shown critical deficiencies. . . Experience with the existing immigration quota system, in particular, has pointed up the need for amending the law. ...

RESOLVED, r. We urge that McCarran-Walter Act be revised and liberalized, to reflect the democratic and humanitarian traditions of our country....

Victor Reuther testified before the Senate Judiciary Committee in November 1955: ". . . we are vehemently opposed to [the national-origins system] as not being consistent with the best in American traditions." 115 He explicitly rejected the racist assumptions underlying the national-origins system and called our present quotas "phony." In labor's judgment, he said, the admission of 250,000 aliens annually would not depress our wage scales, and he stated that fears to that effect were not well-founded. At these same I955 congressional hearings, the AFL representative testified that the McCarran-Walter Act "will require substantial modification if it is to serve as a suitable framework for the nation's immigration policy."116

\section{Other Groups}

Among the other powerful voices urging change of the present law are leading bar associations. The American Bar Association has taken vigorous exception to basic procedural defects and shortcomings and has urged extensive legislative amendments to rectify these critical faults. ${ }^{117}$ The Bar Association of the District of Columbia, ${ }^{118}$ The State Bar of California, ${ }^{119}$ and the New York County Lawyers Asso-

${ }^{111}$ See Starr, Labor and Immigration, 29 CuRReNt History 300 (I955).

${ }^{112}$ Sce Hearings, op. cit. supra note 9, at 1620 .

${ }^{113} \mathrm{Id}$. at $\mathrm{I} 607$.

${ }^{114}$ American Immigration Conference, News, April 5, 1956, p. 6.

110 Hearings, stupra note 37 , at I Transcript 4 et seq.

${ }^{110} I d$. at 46.

${ }^{117}$ Sec 9 AD. L. BuLl. 7 (1955).

${ }^{118}$ See Resolution of Board of Directors, Dec. 9, I955, approving report of Subcommittee on Immigration Bills. Hearings, supra note 37. This approval was preceded by a written referendum of the total membership of the Administrative Law Section of the Bar Association.

${ }^{110}$ See 30 Calif. B. J. 322 (1955). 
ciation, ${ }^{120}$ are other examples of this growing tide of opposition among lawyers and bar associations to the present immigration law.

Another developing form of organized public opinion having considerable influence is the representative local, regional, or state group organized to study immigration and nationality problems and to bring the facts and policy issues to the attention of its own community. At the 9955 senate hearings, representatives of such responsible community-wide groups in St. Louis ${ }^{121}$ and San Francisco ${ }^{122}$ testified in opposition to the national-origins system.

In a free society, honest, open, and above-board group representation has an important role to play in the welding of public policy.

A democratic society, then, is one in which all interests are mobilized, organized and articulate, in which all are alerted to their welfare, in which all present their claims and take an active part in the process of group conflict, compromise and adjustment. ${ }^{123}$

In major degree, this "active part" has been taken, until very recently, only by the supporters of the McCarran-Walter Act. Both the President's Commission and the Gallup Poll found a consensus opposed to that law. But that consensus of opposition was not "alerted" and certainly was not "mobilized, organized and articulate." There are signs which indicate, however, that this one-sidedness is being redressed, that the groups which represent the American people's consensus of opposition to present immigration law may be undertaking to become more articulate, and that a mass movement within the American people has begun toward the development of a public demand for basic revision of the present immigration law.

\section{General Posture of the Immigration Issue Today}

"[S]eldom in our history have so many violent attacks been made on a Congressional action as have been made on the McCarran Act."124

\section{New Attitude}

Even among those normally regarded as defenders of the status quo, a wholly new attitude has developed, more conducive to open-minded willingness to amend the present law and to regard it as less than sacrosanct. This subtle, but extremely important, change in public attitude is illustrated in a letter published in a recent Bulletin of the District of Columbia Society of Sons of the American Revolution: ${ }^{125}$

We have had, in our whole history as a country, only a generation of experience with the quota system. Whatever the merits of the several bills now pending in Congress, to suggest that considering change in the present law is a violation of the spirit and history

${ }^{120}$ See 9 Cong. Q. Almanac 242 (1953).

${ }^{121}$ See Hearings, supra note 37 , at 4 Transcript 427 .

122 See id. at 432 .

${ }^{123}$ Carleton, Political Science and the Group Process, 54 S. Atzantic Q. 340, 347 (1955).

${ }^{124}$ Heckman, Our Immigration Laws, $A$ Continuing Affront to the Administrative Procedure Act, $4 \mathrm{I}$ Geo. L. J. 364 (1953).

${ }^{125}$ D. C. Society of the Sons of the American Revolution, Bulletin, Jan. I956, p. 1. 
of our country is simply not the case. To suggest that there is something subversive about considering changes in the law is equally false.

Even the DAR has witnessed this new attitude. At its $65^{\text {th }}$ Continental Congress, April 1956, there was opposition on the floor to the national-origins system as "illogical" and "patently absurd," protest against "blind support" of the present law, without time to study the resolutions, and a plea, "do not close our minds... to reason and enlightenment."126

Contributing to this new general attitude is the widespread realization that the pseudo-scientific basis for the national-origins quota system has been completely and thoroughly discredited. ${ }^{127}$ This has been recognized even in that stronghold of the McCarran-Walter Act, the Senate Judiciary Committee. ${ }^{128}$ Most of the supposed justifications for the national-origins theory ${ }^{120}$ have been shown to be nonsense, if not worse. The entire scientific climate of opinion today is that the national-origins theory is utterly without basis in demonstrable fact. ${ }^{130}$

\section{New Leadership of the United States.}

Another part of the reason for this basic change in public attitude is the difference in our national orientation between the early twenties and today. ${ }^{131}$ The national-origins quota system was adopted by legislators who rejected the League of Nations, who wanted the United States to withdraw from world affairs. It was enacted at a time of strong undercurrents of racial and religious prejudice, most dangerously exemplified by the Ku Klux Klan and the development of the ideology of Nordic supremacy. It matured at a time of labor's fear for the future. Today, we have a different domestic and international situation. The United States is a world leader, one of the founders and strongest supporters of the United Nations. We have waged and won a war to defeat the Nazi theory of superior races and are engaged in a bitter struggle against Communism for the minds of men around the world. Labor's position and our economy no longer look backward, but forward. The world has changed, and with it, the attitude of the American people; the realization has grown that the national-origins theory is a serious detriment to our national welfare and security.

As a result of these new developments, revision of our immigration law has become an important public issue. For decades, it was not the thing to talk about; now, editorials appear regularly in leading newspapers around the country ${ }^{132}$

${ }^{120}$ Evening Star (Washington, D. C.), April 19, 1956, p. 1, col. 3; p. 3, col. 5; N. Y. Times, April 20, 1956, p. 8, col. 5; x02 Cong. Rec. 6ri3 (daily ed. April 24, 1956).

${ }^{127}$ Sce President's Comim'n on Immigration and Naturalization, op. cit. stipra note 3, at 91-96; Hearings, stipra note 9, at 1843 et seq.; Handlin, Discredited Doctrines of the McCarran-Walter Act, Catholic Charities Rev., March r953, p. 69 .

${ }^{128}$ See National Council of Churches, supra note 79, at 3.

${ }^{120}$ See S. Doc. No. 747, 6rst Cong., 3 d Sess. (I910).

${ }^{130}$ See Peterson, The "Scientific" Basis of our Immigration Policy, 20 Commentary 77, 80 (1955).

${ }^{131}$ Sce President's Comm's on Immigration and Naturalization, op. cit. supra note 3, at 86; Hearings, supra note 9, at 1862 .

${ }_{132}$ See, e.g., San Francisco Call-Bulletin, I02 CoNG. REc. I299 (daily ed. Jan. 27, 1956); N. Y. Journal-American, $i d$. at $\mathrm{Ar}_{2} \mathrm{O}_{3}$ (daily ed. Feb. 7, 1956). 
Our public and private leaders have begun to realize that the present immigration law damages our status abroad, ${ }^{133}$ and outstanding citizens and statesmen feel it necessary publicly to urge fundamental changes in our law. ${ }^{134}$

\section{A Political Issue.}

Revision of our immigration law has become a lively and very popular political issue, in presidential as well as off-year elections. After some 96 years of either quiescence or active restrictionism, an abrupt change occurred in 1952. President Truman's veto articulated the opposition which many had been feeling to the national-origins theory and our restrictive immigration legislation. Immigration was an issue in the 1952 campaign, ${ }^{135}$ with both Republican and Democratic presidential and vice-presidential candidates promising major amendments to the national-origins and other restrictive features of the McCarran-Walter Act. The Democratic Party's I952 platform contained a basic pledge to amend the McCarran-Walter Act. The Democratic majority leader of the present Senate has urged immigration reform, the first time a senate majority leader has ever done this. ${ }^{136}$ President Eisenhower has sent to Congress a special message on immigration, requesting extensive reforms in the law. Perhaps for the first time in our national history, 1956 will see both political parties with platform planks urging substantial liberalization of our immigration law. Far-reaching amendment to the McCarran-Walter Act almost certainly will be an important political issue in the 1956 presidential elections. ${ }^{137}$

The chief of the Washington Bureau of the New York Times, James Reston, recently said that "timidity" is the "occupational disease" of politics. ${ }^{138}$ He stated, as a political truism, that "candidates seldom say unpopular things." If that be so, advocacy of basic amendment of the McCarran-Walter Act has become not only an important but apparently also a popular and "safe" political issue. Politicians and political parties apparently must be finding an important and widespread demand from their constituencies for basic and extensive amendment of the McCarranWalter Act.

\section{Congressional Awareness of Defects}

Congress itself knows that there is something radically wrong with the nationalorigins system. Congress itself discarded the national-origins system, pro tanto, when it enacted the Displaced Persons Act, which ignored national origins by "mortgaging" future quotas. ${ }^{139}$ Congress went even further when it enacted the

${ }^{133}$ See President's Comm'n on ImMigration and Naturalization, op. cit. sllpra note 3 , at 47 et seq.; Van Kirk, yoo CoNG. Rec. A4032 (I954); testimony of Secretary of State, Hearings, stipra note 37, at 6 Transcript 566; and N. Y. Times, April 26, 1956, p. 13, col. 1.

${ }^{134}$ See, e.g., Paul Hoffman, Hearings, stipra note 37, at 3 Transcript 254; and David Sarnoff, 102 Cong. Rec. 83 (daily ed. Jan. 5, x956).

${ }_{135}$ See, e.g., U. S. News and World Report, Oct. 31, 1952, p. 26; Lefever, supra note $3^{8}$, at $3^{8}$.

${ }^{130}$ See statement of Senator Thomas G. Hennings, Hearings, supra 37, at 3 Transcript 249.

${ }^{137}$ See 94 AMERICA 290 (1955).

${ }^{138}$ N. Y. Times, April 9, I956, p. I6, col. I-2.

${ }^{139} \mathrm{H}$. R. 10087, $84^{\text {th }}$ Cong., $2 \mathrm{~d}$ Sess. (1956) (introduced by Mr. Walter) would climinate quota "mortgages." 
Refugee Relief Act of 1953 which made admissions completely nonquota, without any reference to national origins. ${ }^{140}$

The steadily increasing number of private bills, whose only purpose is to repeal the general immigration and nationality law in specific meritorious cases, is further proof of congressional awareness of the inequities and injustices caused by the McCarran-Walter Act. ${ }^{141}$ This has special significance because the proponents of the McCarran-Walter Act had assured that its enactment would reduce the flood of private immigration legislation. ${ }^{\mathbf{1 4 2}}$

\section{Administration Position}

An important aspect of immigration's present posture is that the administration's machinery, through its executive departments, is openly urging extensive revisions of the McCarran-Walter Act. This was not so in 1952. Although President Truman vetoed the bill, his Secretary of State and his Attorney General supported it during the legislative process, or at least never openly opposed it $^{143}$ until after its enactment. ${ }^{144}$ Now, the Attorney General has publicly said that the law "needs drastic amendment."145 Before the Senate Judiciary Committee, on April I3, I956, the Attorney General testified: ${ }^{146}$

The President stated in his Message that the time has come to re-examine and revise the existing quota system. He pointed out that the root of the problem lies in the use of national origins as a basis for quotas ... I urge the Congress to appropriate the necessary funds to fully explore this difficult quota problem with a view to establishing a new, basic immigration policy.

When asked at the hearing whether the President's proposal for pooling unused quotas would "transfer the cultural pattern" of immigration to southern and eastern Europe, the Attorney General replied: "I don't recognize that cultural pattern."147

The Secretary of State also testified, on April 25, 1956, that revision of the McCarran-Walter Act is "necessary and desirable in the interest of the United States." He directly attacked the national-origins system: $:^{148}$

Our quota restrictions should not discriminate among persons merely on the basis of their national origins, nor should the restrictions discriminate unfairly against any of the

${ }^{160} 67$ StAT. 400, 50 App. U.S.C. § 1971 (Supp. 1955).

${ }^{181}$ According to information from the Immigration and Naturalization Service, there were 2,8ro private bills in the first session of the 84 th Congress, 4,797 in both sessions of the $83 \mathrm{~d}, 3,669$ in the $82 \mathrm{~d}, 2,8 \mathrm{II}$ in the $8 \mathrm{rst}, \mathrm{I}, \mathrm{I} 4 \mathrm{I}$ in the 80 th, and 429 in the 79 th Congress. See also President's Comm' on ImMigration and Naturalization, op. cit. sipra note 3, at 107-8.

${ }_{142}$ See, e.g., 98 Cong. Rec. 4307-08 (1952).

${ }^{143}$ See Hoskasha, Behind the McCarran Anti-Immigration Bill, The New Leader, June 9, 1952, p. 2; loint Hearings on S. 7r6, 82d Cong., xst Sess. 245, 280, 708, 711, 723.

${ }^{14 "}$ See Hearings, stipra note 9, at 1350 (Attorney General); id. at 1412 (Secretary of State).

${ }^{165}$ The Evening Star (Washington, D. C.), Dec. 6, I955, p. B-2, col. I-2.

${ }^{100}$ Hearings, stipra note 37 , at 5 Transcript 517.

${ }^{117}$ Ibid.; N. Y. Times, April 14, 1956, p. 37, col. 2-3.

${ }^{14}$ Hearings, supra note 37 , at 6 Transcript $566-67$; N. Y. Herald Tribune, April 26, I956, p. 3, col. 4; Chamber of Commerce of the U. S., Legislative Daily, April 26, 1956, p. I52. 
friendly nations which have an interest in common with us in the defense of the free world. The present system of determining quotas is offensive on both counts.

He specifically rejected national origins as a basis of selecting immigrants: ${ }^{140}$

In my opinion, the national origins quota system, which draws a distinction between the blood of one person and the blood of another, cannot be reconciled with the fundamental concepts of our Declaration of Independence which, as Abraham Lincoln said, applied not only to this country but to all men and meant "that all should have an equal chance."

The Secretary of State urged Congress "to devise a system of quotas which is not tied to the discriminatory national origins," and, in the meantime, to adopt the interim plan of pooling unused quotas, as proposed by the President. ${ }^{160}$

Administration willingness to "carry the ball" for amendment of the law is of utmost importance. Because of the situation within the Judiciary Committees, it will take all the prestige, power, and persuasion not only of the President and his White House associates, but also of the Departments of State and Justice to obtain liberalizing amendments. Such was the experience learned from the successful fight by President Truman and the Displaced Persons Commission to obtain the $195^{\circ}$ amendments to the Displaced Persons Act of I948; bowling over an adamantly dissenting congressional committee chairman is no task for half-hearted people; ${ }^{\mathbf{1 5 1}}$ it demands an all-out effort by the President and his executive agencies.

\section{Citizen Awakening}

Although the Gallup Poll showed that the knowledgeable people in the nation want to have our immigration law basically amended, ${ }^{152}$ it is still probably basically true, as Senator Lehman recently stated, that "... the people [as a whole] do not know the facts." Archbishop Cushing, too, has said that "one of the great difficulties about immigration during the past thirty years has been the lack of broad citizen interest."153

Until the President's Commission's hearings took the issue to grass-roots America in the fall of $195^{2}$, there was substantially little general knowledge about the problem in the country. The Displaced Persons Act of 1948 was forced to a successful vote, as were the $195^{\circ}$ amendments, because of a wave of feeling throughout the nation that something had to be done. On the other hand, a small band of determined men was able to get the McCarran-Walter Bill enacted in $195^{2}$ "in the half-light of public inattention." ${ }^{254}$ The people simply did not know what was going on in this respect. General public knowledge of the immigration law and of its policy assumptions, effect, and significance is essential if the law is faithfully to reflect national ideals. This citizen awakening has already begun.

\footnotetext{
${ }^{169}$ Hearings, supra note 37, at 6 Transcript 567; N. Y. Times, April 26, 1956, p. 13. col. 3-4.

${ }^{150}$ Hearings, supra note 37 , at 6 Transcript 569 .

181 Cf. BaILEY \& SaMuel, op. cit. supra note 49 , at 240.

162 See Hearings, supra note 69. See also 94 AMErica 574 (1956).

${ }^{153}$ Cushing, supra note 99, at 367.

${ }^{154}$ Handlin, The Immigration Fight Has Only Begun, I4 CoMmentary I, 4 (1952).
} 


\section{A LoOK into the Future}

What are immediate prospects? Let us return to the questions posed at the outset:

\section{Whether}

Whether Congress will act is in the hands of the American people. If Gallup is correct that most Americans are unaware of the issue, but that those who are informed are preponderantly opposed to the present law, the answer is clear. When the American people become fully aware of the import of their immigration law, they will compel a complete and basic revision of the law and the elimination of the national-origins system. To accomplish this objective, however, will be no easy task. Responsible bipartisan co-operation and joint planning will be needed. In the fight to amend the Displaced Persons Act of 1948 , for example, the Democratic majority leader of the Senate appeared, by invitation, before the Republican Policy Committee in an effort to work out bipartisan plans. ${ }^{155}$ There, too, a determined public opinion won its battle despite the split on policy within the party controlling the Congress and over the violent opposition of the opposing forces in control of the congressional committee structure. Then, as now, the party leadership made enactment of such legislation a party "must." Now, as then, the issue can probably be won with cooperation and mutual planning of public and private groups and persons dedicated to elimination of the certain features from our immigration law.

How

Will these amendments take the form of a frontal attack on the McCarranWalter Act, as proposed by the President's Commission on Immigration and $\mathrm{Na}$ turalization and appearing in the form of the bills by Senator Lehman and his colleagues? Will they be in the more limited, but still far-reaching, proposals made by President Eisenhower? Or will they be in the tangential manner proposed by Congressman Walter and others?

"Piecemeal changes in this law," said Adlai Stevenson, "however well-intentioned, are certain to be unsatisfactory, because the many sections of the immigration code are so interwoven as to make a complete revision with a new and more humane approach, the best remedy." ${ }^{156}$ On the other hand, many people of good will and intent urge a more gradual approach. ${ }^{157}$ The Displaced Persons Act is given as an example of the piecemeal approach; President Truman was urged to veto the bill, but signed it, and immediately went to work for its amendment. ${ }^{158}$

The difference between an over-all plan of goals, or strategy, and the specific

${ }^{105}$ See BAILEY \& SAMUEL, Op. cit. stipra note 49, at 249-50.

${ }^{150}$ roz Cong. Rec. 80-8I (daily ed. Jan. 5, r956).

${ }^{107}$ See, e.g., American Immigration Conference, Forty Recommendations for Amending the Immigration and Nationality ACt (1955).

${ }^{108}$ See Displaced Persons Comm'n, op. cit. supra note 54 , at 27 et seq. 
battle plan, or tactics, is important. If the strategy in the fight for the Displaced Persons Act had not encompassed what was ultimately won in the $195^{\circ}$ amendments, it is possible that even the original 1948 law might not have been forced through Congress. The legislative process is one of compromise and jockeying between competing interests. One is always faced with the choice between the "all-or-none" approach and the "half-a-loaf-is-better-than-none" approach. Sad experience has often shown that yielding, or yielding too soon, may result in loss even of the half-loaf.

Substantial progress has been made since 1952 in the course from piecemeal to frontal and thoroughgoing legislative amendments. In the senate debate of the spring of 1952, pooling of quotas was the maximum goal proposed in the substitute offered to the McCarran-Walter Bill.159 By the winter of $1952-53$, the President's Commission recommended a complete abandonment of the national-origins formula and proposed a unified quota system in its place, without regard to national origin, race, color, or creed. President Eisenhower's special message of February 1956 presents pooling of unused quotas as a minimum immediate demand and urges further study geared to dealing with the national-origins system. Senator Lehman, whose bill would carry out the recommendations of the President's Commission, has publicly stated that he will support President Eisenhower's more limited proposals. All such steps, however, ${ }^{160}$ are obviously only first steps toward the ultimate goal so far as both the President and the Senator are concerned.

It would be foolhardy to assume that supporters of the present law are unaware that pooling of unused quotas is a fundamental change in legislative policy and a step toward abandonment of the national-origins system. Else, how explain their bitter opposition to the President's proposal? The racial, religious, and other prejudices supporting the national-origins system-and this is not to say there are not other purported reasons for such support-will fight just as bitterly against pooling of quotas. However, uncommitted people are likely to see in the President's proposal a reasonable step forward and may be willing to accept it while they are becoming better informed as to the real and full needs of our nation's immigration policy.

Another possibility rests in technical or small-range amendments. Like the Supreme Court in its refusal to consider constitutional issues unless absolutely necessary, Congress generally does not tackle more than it has to or is compelled to by public opinion. Although major public needs and world crises have proved that the national-origins law has broken down and is a national detriment, Congress has not, until now, attacked the real evil of the national-origins system. Instead, it has enacted special emergency laws, such as the Displaced Persons Act, the Refugee Relief Act, the War Bride's Act, and even some of Senator McCarran's special bills

${ }^{160}$ S. 2343, 82d Cong., Ist Sess. (I95I). See Handlin, supra note 154 , at 6.

${ }^{100}$ The possibilities of this approach are legion. See, e.g., Rosenfield, Consular-Nonreviewability: A Case Study in Administrative Absolutism, 41 A.B.A.J. I rog (1955); Maslow, Recasting Our Deportation Law: Proposals for Reform, 56 ColuM. L. Rev. 309 (1956). 
admitting sheep-herders without regard to general legal requirements. ${ }^{161}$ Competent observers have noted an inclination on the part of defenders of the present law to approve technical and even minor policy amendments. In the current session of Congress, if any legislation is enacted, it is likely to be a combination of, or resemble the contents of, Congressman Walter's two bills, H.R. 6888 and H.R. I0087, which propose technical changes in the McCarran-Walter Act and the Refugee Relief Act.

There seems to be small likelihood that either Senator Lehman's frontal attack or the President's sideswiping attack on the national-origins system will even receive serious consideration from the Judiciary Committees this session. However, the educational campaign now under way, on the part of church, labor, civic, and other groups, should soon reach the bulk of the American people. The election campaign of $195^{6}$ will be fought, in some part, over the immigration issue. As the American public becomes aware of the issues, it would seem that fundamental, far-reaching, and all-inclusive revisions of our immigration law must inevitably follow. The process of change of these laws, therefore, will likely start piecemeal, with amendments geared to the long-range goal of basic change. And this very process will probably result ultimately in a complete revision through frontal attack on the present law.

\section{What}

What will these forthcoming amendments provide?

a. The tone of the law. Perhaps this may be the most difficult to change. Men live by symbols, and a "tough"-sounding law may be a face-saving device for a Congress that will liberalize content. So, in the Displaced Persons Act, many congressmen and senators found solace and self-defense in calling that law "a quota law," although for practical operational purposes, it completely ignored and wiped out the quota limitations. Liberalized immigration administration, plus the new developing public opinion, will lead the way to a sounder and more just orientation of the law.

b. The number to be admitted. Substantial agreement has been reached by both political parties for an increase in the number of aliens authorized to be admitted annually. Within the foreseeable future, it is reasonable to expect an amendment to this general effect, somewhere between the 220,000 recommended by President Eisenhower and the 250,000 recommended by the President's Commission on Immigration and Naturalization.

c. Method of selection. This is the critical issue. We have already witnessed the beginning of the end of the national-origins system, first by indirection (such as the "mortgaging" of quotas under the Displaced Persons Act), ${ }^{162}$ then somewhat more openly (as in the nonquota status under the Refugee Relief Act). Now, we have

\footnotetext{
${ }^{101}$ See President's Comm'n on Immigratton and Naturalization, op. cit. supra note 3, at ro708. See also Engel, Letter to Editor, N. Y. Times, July 6, 1954, p. 22, col. 5.

${ }^{102}$ See note 139 supra.
} 
President Eisenhower's proposal (I) to pool unused quotas and (2) to admit 5,000 nonquota aliens. Something in the nature of the President's current proposals probably will be the next legislative step toward the total elimination of the nationalorigins system and the substitution for it of a selective process free of discrimination based on national origin, race, religion, or color.

\section{When}

How soon will such amendments be adopted? Senator Lehman admitted in the senate hearings of November 1955 that he expected no "major revision" of present law in $1956 .^{163}$

The history of former restrictive immigration legislation shows that there is a considerable time-lag between initiation of new proposals and their fruition in legislation. The 19I7 Immigration Act developed out of the work started by the Immigration Commission of 1907-a ten-year lag. The 1921 Act saw its first progenitor in a bill introduced in $19 \times 3^{164}$-here, there was an eight-year gestation period. The McCarran-Walter Act of 1952 began its legislative history in 1945, as a result of a general investigation of immigration and nationality laws $s^{165}$-this took seven years.

The new immigration law, which will replace the McCarran-Walter Act, began its legislative journey when the conscience of America was aroused first by President Truman's veto in $195^{2}$ and then by the report, Whom We Shall Welcome, issued by the President's Commission in 1953. The presidential election campaign of 1952 just barely opened up public debate on immigration. The 1956 election campaign promises to serve as the first really full-scale, national political forum for public education, discussion, and decision, on the immigration issue. It would seem not too rash to expect, then, that by the rg6o presidential campaign, the general policy decisions will have been reached by the American people. By then, the pattern of public attitude and the responsiveness of Congress to this new and by then well-developed public demand will assure substantial and fundamental revisions to enable our immigration law to reflect our highest ideals, serving the national interest, without discrimination based on national origins, race, color, or religion, and without the petty meanness of our present immigration law. By Ig60, it seems safe to predict, the American people will have set their sights on a complete and thorough revision of our immigration law, along the lines charted in 1953 by the President's Commission on Immigration and Naturalization. Once the American people know the facts, it is unlikely that they will tolerate immigration laws that reflect distrust, discrimination, and dangerous isolation. They will demand a positive, liberalized immigration policy consonant with our great traditions and our role as a great world power.

${ }^{163}$ See 35 Cong. Dig. I (1956); 102 Cong. Rec. A662 (daily ed. Jan. 23, 1956).

${ }^{104}$ See Note, Developments in the Law of Immigration and Nationality, 66 HaRv. L. Rev. 643, 648 (1953).

${ }^{106}$ H. REs. 52, 79th Cong., Ist Sess. (1945). See also, H. REp. No. 1312, 79th Cong., Ist Sess. (1945); S. Res. 137, 80th Cong., Ist Sess. (1947); S. REp. No. 1515, 84th Cong., Ist Sess. (1955). 